\title{
Arthropod predation of black grass bugs (Hemiptera: Mir- idae) in Utah ranges
}

JAIME E. ARAYA AND B. AUSTIN HAWS

\section{Abstract}

The predation by selected arthropod predators on immature and adult black grass bugs (BGB), Labops hesperius and Irbisia brachycera, on Utah ranges was investigated. Adult Nabis alkernatus was found to be the most important predator of BGB; this species is particularly abundant in early spring and was observed preying on BGB both in the field and in laboratory feeding tests. Immature nabids consumed the bugs but preyed mostly on leafhoppers, smaller plant bug nymphs, and other immature nabids. Nabis vandureei showed potential as a predator of adult BGB in the laboratory feeding tests. Spiders were important predators of BGB. Based on predation of BGB in field and laboratory studies, the spiders observed were ranked as follows from greatest to least importance as predators: Xysticus cunctator, Misumenops lepidus, Tibellus sp. (Thomisidae), Castianeire sp. (Clubionidae), and Tetragnatha sp. (Araneidae). Spiders attacked any prey of a size similar to themselves, but they also preyed on beneficial arthropods, including nabids and other spiders.

Key Words: wheatgrass, Lycosidae, Metepeira foxi, Paradecerla formicina, wolfspiders

Large areas of rangelands in Utah and other western states have been seeded to introduced wheatgrasses (Agropyron sp.) which are infested with the univoltine black grass bugs (BGB) Labops hesperius Uhler and Irbisia brachycera Uhler (Hemiptera: Miridae) (Hewitt et al. 1974, Rogler \& Lorenz 1983). The BGB hatch as soon as the winter snow melts and begin to feed on and damage grasses during the critical early spring stage of plant growth (Brewer et al. 1979). The damaged grasses develop a yellow to whitish mottling marked with small, black fecal spots. Heavily affected grasses may eventually become completely dry. Severely damaged plants seem to be unattractive to livestock (Haws et al. 1973, Higgins et al. 1977, Malechek et al. 1977).

The major BGB species in Utah appears to be $L$. hesperius, but $L$. hirtus Knight and $L$. utahensis Knowlton are also important in certain areas (Knowlton 1945, Haws et al. 1973, Hewitt et al. 1974). Details on the biology of $L$. hesperius can be found in the review by Araya (1982). Another important BGB, I. brachycera, has apparently been responsible for much of the damage formerly attributed to Labops (Hewitt et al. 1974). BGB are not usually present in large numbers on native grasses (Higgins et al. 1977) or in areas intermixed with native plants (Haws et al. 1973), probably in part because these ranges provide a good habitat for insect-eating arthropods.

The management of crop pests through biological and integrated control methods requires an understanding of the complex interactions between the pests and beneficial insects (Smith et al. 1976). While beneficial arthropods are essential elements in integrated pest control, very little is known concerning their relative efficiency in controlling pest species (Wilson and Gutierrez 1980).

\footnotetext{
Authors are associate professor of entomology, Departamento de Sanidad Vegetal. Facultad de Ciencias Agrarias y Forestales, Universidad de Chile. Casilla 1004 Santiago, Chile, currently at Dept. of Entomology, Purdue Univ., W. Lafayette, Ind. 47907; and professor of entomology, Dept. of Biology, UMC 53, Utah State Univ., Logan 84322

The contributions of our colleague entomologists Eric Coombs and Roy Meadows during these studies, the identification of spider species by Dr. Eric Zurcher, Utah State Univ., and Dr. W.J. Gersh, Univ. of Arizona, and of ants by Dr. George C. Wheeler, San Antonio, Texas, are greatly appreciated.

Manuscript accepted 29 October 1987
}

Information about predators of insects in rangeland grasses is particularly scarce.

Most predators are polyphagous, thus a direct predator-prey relationship is difficult to ascertain. Knowledge of the seasonal abundance of predaceous arthropods is helpful in defining their roles in regulating insect pests. This information is essential for developing effective insect pest management programs (Shepard et al. 1974). Many predators can be observed in rangelands, but the effectiveness of each species is difficult to evaluate in field studies. Cage tests in the greenhouse might be a preliminary step in establishing an index of predator efficiency against each prey species. Such an index can be used for planning integrated control programs (Tamaki and Weeks 1972).

The objectives of this study were: (1) To identify major potential invertebrate predators of BGB in selected Utah ranges, and (2) To compare predation by adult and immature invertebrate predators on selected range insects under laboratory conditions.

\section{Materials and Methods}

These studies were conducted in BGB-infested rangelands near Porterville, Morgan Co., Utah; Logan, Cache Co., Utah; Hodge Creek, Logan Canyon, Cache Co., Utah; and the wheatgrass ranges around the Alpine Cabin of the Intermountain Research Station, Ephraim Canyon, Sanpete Co., Utah. A brief description of the study sites appears in Table 1. Laboratory studies were conducted in the Range Entomology Laboratory, Department of Biology, Utah State University, Logan.

\section{Procedures for Objective 1}

A $38.1-\mathrm{cm}$ diameter sweep net was used to collect insects and spiders periodically during the growing seasons of 1981 and 1982 from selected grasslands with BGB (Table 1). Litter sampling on the same dates and fields was helpful particularly in providing immature BGB specimens. Pitfall traps helped in identifying the species of arthropods present, but were considered unreliable because of the different behavior responses they induced on different species of arthropods, as evident in preliminary studies, and because they provided mostly dead or damaged specimens. Quantitative data on arthropod abundance is described by Araya (1982).

\section{Procedures for Objective 2}

Live BGB and insect predators were separated from the material collected with the sweep net and from the litter sampled (particularly for immature BGB) by using an aspirator, a small hair brush, or grass leaves or stems that some insects readily grasp. Spiders were separated with forceps. Three studies were designed.

\section{Studies of Predation with One Species of Prey Per Predator, Growing Season of 1981}

Ten adults of either $L$. hesperius or $I$. brachycera were caged with one adult predator of each of the selected predator species (the most abundant in the field), in transparent plastic cylinders $25 \mathrm{~cm}$ high and $9 \mathrm{~cm}$ diameter. Each cylinder was covered with a screen lid and had a vial holding a small clump of live wheatgrass (Agropyron sp.) on the bottom on which the BGB could feed (Araya 1982). BGB mortality was recorded every 2 days, and the dead insects were replaced with live ones. There were at least 5 replica- 
Table 1. Some invertebrate predators of black grass bugs collected from selected Utah rangelands during the 1981 and 1982 growing seasons.

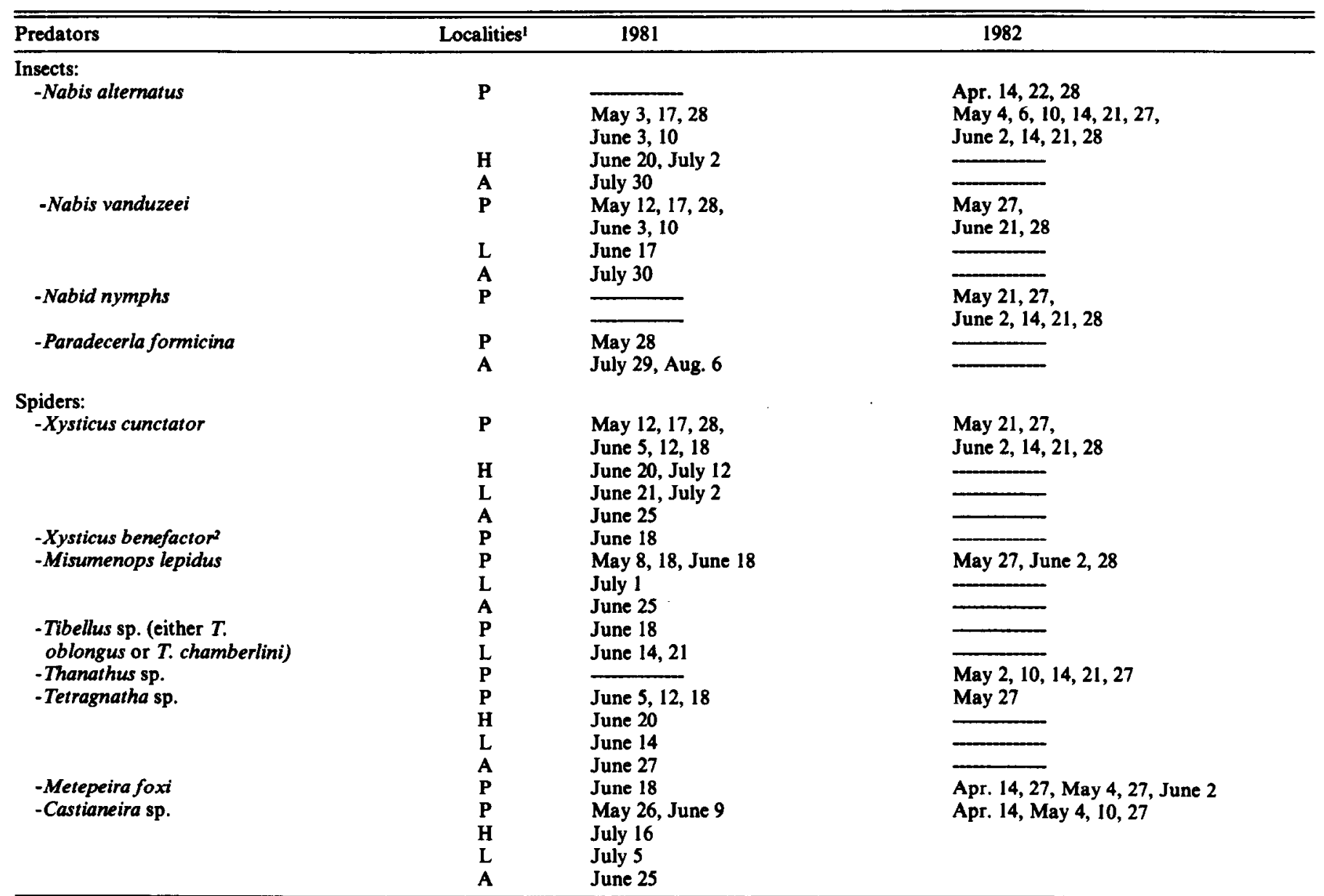

${ }_{1} \mathbf{P}=$ Porterville, Morgan Co., UT (wheatgrass monoculture on about $1,600 \mathrm{~m}$ elevation hillside fields. $\mathrm{L}=\mathrm{L}$.gan (semi urban field with diverse grasses and forbs, about $1,400 \mathrm{~m}$ elevation), Cache Co, UT. H = Hodge Creek, Logan Canyon, Cache Co., UT (a field patch surrounded by shrub and tree species, on a creek about $2,000 \mathrm{~m}$ elevation). A = Fields around the the Alpine Cabin of the Intermountain Res. Exp. Sta., Ephraim Canyon, Sanpete Co., UT.

2One male specimen, identified by Dr. W.J. Gersh, Univ. of Arizona.

tions of 10-day long tests for each individual predator tested, although more replications were used for some species. BGB natural mortality was evaluated from control cylinders containing no predators. Ten-day long tests were repeated at different times of the growing season to test for consistency of the results, which was verified since these replications were not significantly different.

Studies of Predation with One Species of Prey Per Predator, Growing Season of 1982

Five-day experiments similar to those of 1981 were conducted in 1982 , but the plastic cylinders were replaced with $5 \mathrm{~cm}$ diameter Petri dishes lined with moistened filter paper. The Petri dishes facilitated handling of the predators and mortality data were more rapidly collected, compared to the $10-\mathrm{cm}$ cylinders used the previous year. Each Petri dish contained a grass clump (Poa sp., a suitable host plant for BGB, as seen in preliminary observations), that was tied with filter paper around the base to keep the grass fresh. Filter paper liners and food were replaced every $48 \mathrm{~h}$ to reduce mortality due to waste accumulations. The number of adult or immature BGB per predator and replication was increased from 10 to 20. Mortality of BGB was recorded every $24 \mathrm{~h}$ and the dead prey were replaced with live insects. At least 5 replications of 5-day tests per predator were used in tests with immature BGB. Five replications were always used in tests with adult $B G B$.

Because of the varying number of replications, the differences in BGB mortality detected through ANOVA in 1981 (Table 2), and in 1982 with immature prey (Table 3), were compared using the " $t$ "
Table 2. Mean numbers of dead adult Labops hesperius and Irbisia brachycera after exposure to selected predators, in numbers of prey dead each $48 \mathrm{~h}$ from a total of ten individuals per cyclinder and predator in 1981 (means of ten-day lons feeding trials).

\begin{tabular}{lll}
\hline \hline Treatments & \multicolumn{2}{c}{ Numbers of dead prey } \\
\cline { 2 - 3 } (predators) & Labops & Irbisia \\
\hline -Xysticus cunctator & $6.03 \mathrm{a}$ & $6.14 \mathrm{~b}$ \\
-Tibellus sp. & $5.92 \mathrm{a}$ & $\ldots$. \\
-Tetragnatha sp. & $4.24 \mathrm{~b}$ & $6.10 \mathrm{~b}$ \\
- Misumenops lepidus & $3.80 \mathrm{bc}$ & $5.96 \mathrm{~b}$ \\
- Nabis vanduzeei & $3.25 \mathrm{~cd}$ & $7.15 \mathrm{a}$ \\
- Castianeira sp. & $3.00 \mathrm{~cd}$ & $5.64 \mathrm{~b}$ \\
- Nabis alternatus & $2.67 \mathrm{~d}$ & $5.72 \mathrm{~b}$ \\
-Control & $0.94 \mathrm{C}$ & $4.10 \mathrm{c}$ \\
\hline
\end{tabular}

Results in the same column followed by different letters are significantly different $(P<0.05)$, according to tests of significance utilizing the " $t$ " distribution between means of non-paired samples with different numbers of observations (LeClerg et al. 1962, Araya 1982).

distribution method between means of non-paired samples (LeClerg et al. 1962, Araya 1982). Significant differences in mortality of adult BGB in 1982 detected in an ANOVA were separated using the Duncan multiple range test (Duncan 1955).

Studies of Predator Preference

Whole samples of the arthropods collected periodically with the 
Table 3. Mean numbers of dead immature and adult Labops hesperius and Irbisia brachycera after exposure to selected predatora, in numbers of prey dead each $24 \mathrm{~h}$ from a total of 20 individuals per Petri dish and predator in 1982 (means of fiveday long feeding trials).

\begin{tabular}{|c|c|c|c|c|c|}
\hline \multirow[b]{3}{*}{ Treatments (predators) } & \multirow[b]{3}{*}{ Stage of development } & \multicolumn{4}{|c|}{ Numbers of dead prey } \\
\hline & & \multicolumn{2}{|c|}{ 3rd-4th instar nymphs 1} & \multicolumn{2}{|c|}{ Adults $^{2}$} \\
\hline & & Labops & Irbisia & Labops & Irbisia \\
\hline $\begin{array}{l}\text {-Nabis alternatus } \\
\text {-Xysticus cunctator } \\
\text {-Misumenops lepidus } \\
\text {-Nabid nymphs } \\
\text {-Wolf spiders (Lycosidae) } \\
\text {-Castianeira sp. } \\
\text {-Tetragnatha sp. } \\
\text {-Formica spp. } \\
\text {-Tanathus sp. } \\
\text {-Control }\end{array}$ & $\begin{array}{l}\text { Adults } \\
\text { Adults } \\
\text { 3rd instar } \\
\text { 3rd instar } \\
\text { Adults } \\
\text { 4st instar } \\
\text { 3rd instar } \\
\text { Adults } \\
\text { Adults } \\
\text {........ }\end{array}$ & $\begin{array}{l}5.26 \mathrm{a} \\
\ldots \\
\ldots \\
1.76 \mathrm{~b} \\
1.36 \mathrm{bc} \\
1.20 \mathrm{bc} \\
1.12 \mathrm{bc} \\
1.07 \mathrm{bc} \\
0.76 \mathrm{c} \\
0.90 \mathrm{c}\end{array}$ & $\begin{array}{l}4.09 \mathrm{a} \\
\ldots \\
\ldots \\
\ldots \\
0.92 \mathrm{c} \\
2.08 \mathrm{~b} \\
\ldots \\
1.09 \mathrm{c} \\
2.12 \mathrm{~b} \\
0.90 \mathrm{c}\end{array}$ & $\begin{array}{l}3.56 \mathrm{a} \\
\ldots \\
3.44 \mathrm{a} \\
3.04 \mathrm{ab} \\
\ldots \\
\ldots \\
\ldots \\
\ldots \\
2.44 \mathrm{bc} \\
1.92 \text { c }\end{array}$ & $\begin{array}{l}4.28 \mathrm{a} \\
3.12 \mathrm{~b} \\
2.28 \mathrm{~cd} \\
2.56 \mathrm{bc} \\
\ldots \\
\ldots . \\
2.44 \mathrm{~cd} \\
\ldots .96 \\
1.96 \mathrm{~cd} \\
1.88 \mathrm{~d}\end{array}$ \\
\hline
\end{tabular}

'Results in the same column followed by different letters are significantly different ( $P<0.05$ ), according to tests of significance utilizing the "t" distribution between means of non-paired samples with different numbers of observations (LeClerg et al. 1962, Araya 1982).

${ }^{2}$ Results in the same column followed by different letters are significantly different $(P<0.05)$, according to Duncan multiple range tests (Duncan 1955$)$.

sweep net from the selected Utah ranges infested with BGB (Table 1) were put into transparent acrylic cages $59 \times 30 \times 30 \mathrm{~cm}$ lined with moistened filter paper to avoid dehydration and containing fresh grasses and forbs. All the arthropod specimens in the cages that were observed to be involved in a predatory activity (e.g., specimens in the act of preying or being preyed upon) were collected and identified (Araya 1982).

\section{Results and Discussion}

Nabids and spiders were present throughout the study areas during 1981-1982 (Table 1). Adult Nabis alternatus Parshley overwinter and appear early in the season (Taylor 1949). In early spring, adult $N$. alternatus which have successfully overwintered are practically the only enemies of the early stages of BGB, and help reduce Labops populations at the time of the year when they damage the host plants most (Haws et al. 1973, Higgins et al. 1977, Brewer et al. 1979). Nabis vanduzeei Kirk was also collected and was particularly common near Porterville in June of 1982 . The predatory mirid Paradecerla formicina (Parshley) was abundant in 1981 on the elevated ranges in Ephraim Canyon. Thomisids were the most important spiders preying on BGB, Xysticus cunctator Thorell in particular, because of its abundance and active predation on adult BGB (Araya 1982). Xysticus spp. are very quiet spiders and do not walk when disturbed (Kaston 1972). Second in abundance in 1981 appeared to be Misumenops lepidus Mceler (Hentz). Tibellus sp., another 'crab spider' fairly common in bushes and tall grass (Kaston 1972), was extremely mobile and difficult to handle, but it was observed preying on adult BGB in the field study sites. Misumenops showed an intermediate level of mobility between those of Xysticus and Tibellus. Thanatus sp., another thomisid common on grasses (Kaston 1972), was collected during May of 1982 near Porterville.

Tetragnatha sp. spiders (Araneidae) were commonly collected from grasses in 1981, but were less abundant in 1982. They characteristically waited for their prey hanging from their webs with their long anterior 2 pairs of legs extended in front of their slender and elongated bodies. Castianeira sp. (Clubionidae) was fairly common in all fields examined, but its populations were composed mostly of immature stages. Metepeira foxi Gertsch \& Ivie (Araneidae) was collected in small numbers since it prefers areas with shrubs rather than open grasslands. The majority of spiders in Utah ranges overwinter as immatures. They become active and develop in the spring, maturing into adults during the summer (Dr. Eric Zurcher, Utah State Univ., personal communications, 1982). Most spiders collected in this study during early spring were 3rd instar spiderlings. The specimens collected thereafter were larger and more developed. The exception were 'wolf spiders' (Lycosi- dae). Many mature wolf spiders were observed near Porterville early in both years, but they were difficult to handle. Lycosids were not seen preying on BGB in the field, but because of their abundance they were included in the predation tests of 1982 . However, they did not kill BGB in the laboratory feeding tests. Further studies are required to determine their prey during early spring. Some other spiders collected were not included in the feeding studies because of their scarcity in the field.

Besides the predation on BGB, M. lepidus, Tetragnatha, and Castianeira were observed occasionally preying on leafhoppers in the field. Leafhoppers were very common insects on the rangelands studies. Xysticus cunctator was also observed preying on nabids, grasshopper nymphs, and on its own species. Remains of leafhoppers and small flies were found occasionally in the field hanging from the silky traps of Tetragnatha, Castianeira, and Thanatus.

Tables 2 and 3 summarize the mean mortalities of BGB by selected predators in the 1981-1982 laboratory tests. Spiders, $X$. cunctator and Tibellus in particular, were effective predators of $L$. hesperius. They preyed significantly more on BGB than did the other predators in the 1981 laboratory tests. Following in predatory activity were Tetragnatha and $M$. lepidus. The third most effective group of predators were the two nabid species and Castianeira. This spider is relatively slow compared to BGB, and probably prefers smaller prey, as it was observed preying on leafhoppers and small plant bugs in the field. As opportunistic predators, spiders will attack any prey easy to catch and handle (Lincoln et al. 1967, Howell and Pienkowski 1970), feeding on pests but also on beneficial insects (Whitcomb and Bell 1964).

Irbisia had a higher natural mortality than Labops. This might be attributed in part to the grass (Poa sp.) fed to the BGB. Irbisia may prefer other grasses (Haws et al. 1973). The relatively greater predation on Labops perhaps reflected the greater mobility of Irbisia and their ability to escape from predators in the field. Unlike Labops, the greatest mortality of Irbisia resulted from their exposure to $N$. vanduzeei (Table 2). All other predators tested consumed significantly fewer BGB than this nabid, but they had similar predation levels among themselves. Even though a given predator may be very efficient individually, it may have little impact on a pest if its own field population is small or reduced or if it prefers smaller prey (Wilson and Gutierrez 1980), and also if it is attracted to prey other than the pest species, as reported for Nabis spp. and Geocoris spp. (Knowlton 1943, 1944, 1949, Whitcomb and Bell 1964, van den Bosch and Hagen 1966, Eveleens et al. 1973).

The list of predators tested in 1982 (Table 3) was different from that of 1981 . The 1982 growing season was delayed because of the severe winter, and spiders collected in May were mostly immatures (except Thanatus and wolf spiders). Nabis alternatus, especially 
adults, were the most significant predators of immature and adult BGB both in the laboratory and from field observations, confirming their value during early spring, the most critical time for infested grasslands (Brewer et al. 1979). Second in predation on Irbisia was $X$. cunctator, followed by immature nabids. Other arthropods tested failed to increase the mortality of immature Labops compared to the controls. With the exception of Castianeira on immature Irbisia, immature spiders tested appeared not to be effective predators of immature BGB, probably because of their smaller size. Size is a determinant factor in predation (Howell and Pienkowski 1970, Wilson and Gutierrez 1980). In the 1982 laboratory feeding tests, Xysticus cunctator and M. lepidus preyed effectively on adult BGB. Thanatus did not increase the mortality of immature or adult BGB. This is a very quiet spider and appeared to prey on flying insects such as flies or leafhoppers. However, remains of BGB with signs of having being preyed on where commonly observed on their irregular webs. Further studies are needed to clarify the predatory activity of Thanatus and wolf spiders. Lycosids may have not preyed upon immature BGB because of behavioral changes due to confinement in the Petri dishes. These fast moving spiders tried constantly to escape from the dishes. To avoid this problem, larger containers simulating more closely natural grassland conditions should be used in further studies.

Ants (mainly Formica neogagates Emery, but we collected also some specimens of $F$. subsericea Say) appeared to be only field scavengers and did not prey upon BGB. Scavenging by adult Labops was also observed. After adult Labops were killed by $N$. alternatus during the 1982 tests, some produced exudates, possibly because of the action of digestive enzymes and the humid environment in the Petri dishes. Some adult Labops were observed momentarily tasting the exudate from the dead prey, continuing thereafter with their normal feeding on the grass clumps and sucking water from the moist filter paper. Nabids were observed occasionally inserting their beaks onto the grass both in the field and in the laboratory, apparently tasting the grass sap.

From our field observations and the results of the laboratory feeding tests, we concluded that several beneficial arthropods preyed actively upon BGB. Among them, nabids and several spider species caused significant laboratory mortality of BGB. Further studies on predation (and parasitism) of BGB are needed in order to clarify the relationships between the different components of rangeland ecosystems and to help explain the annual fluctuation in BGB population, in order to preserve these delicate environments, and to provide strong scientific basis for the development of sound integrated pest management systems for range pastures.

\section{Literature Cited}

Araya, J.E. 1982. Studies of selected predators of black grass bugs (Labops hesperius Uhler and Irbisia brachycera Uhler) on ranges of Utah. MS Thesis, Utah State Univ., Logan.

Brewer, P.S., W.F. Campbell, and B.A. Haws. 1979. How black grass bugs operate. Utah Sci. 40:21-23.
Duncan, D.B. 1955. Multiple range and multiple F tests. Biometrics $11: 1-42$.

Eveleens, K.G., R. van den Bosch, and L.E. Ehler. 1973. Secondary outbreak induction of beet armyworm by experimental insecticide applications in cotton in California. Environ. Entomol. 2:497-503.

Haws, B.A., D.D. Dwyer, and M.G. Anderson. 1973. Problems with range grasses? Look for black grass bugs. Utah Sci. 34:3-9.

Hewitt, G.B., E.W. Huddleston, R.J. Lavigne, D.N. Ueckert, and J.G. Watts. 1974. Rangeland Entomology. Soc. Range Manage., Denver, Colo. Range Sci. Series No. 2.

Higtins, K.M., J.E. Bowns, and B.A. Haws. 1977. The black grass bug (Labops hesperius Uhler): Its effects on several native and introduced grasses. J. Range Manage. 30:380-384.

Howell, J.O., and R.L. Pienkowski. 1970. Spider populations in alfalfa, with notes on spider prey and effect on harvest. J. Econ. Entomol. 64:163-168.

Kaston, B.J. 1972. How to know spiders. 2nd. ed., Wm. C. Brown Co., Publ., Dubuque, Iowa.

Knowlton, G.F. 1943. Nabis alternatus feeding observations. Bull. Brooklyn Entomol. Soc. 38:122-140.

Knowlton, G.F. 1944. Observations on the feeding of some predaceous Hemiptera. Proc. Utah Acad. Sci. 21:57-58.

Knowlton, G.F. 1945. Labops damage to range grasses. J. Econ. Entomol. 38:707-708.

Knowlton, G.F. 1949. Predaceous Hemiptera feeding observations. J. Kansas Entomol. Soc. 22:37-39.

LeClerg, E.L., W.H. Leonard, and A.G. Clark. 1962. Field plot technique. 2nd. ed., Burgess Pub. Co., Minnesota.

Lincoln, C., J.R. Phillips, W.H. Whitcomb, G.C. Dowell, W.P. Boyer, K.O. Bell, G.L. Dean, E.J. Mathews, J.B. Graves, L.D. Newsom, D.F. Clower, J.R. Bradley, and J.H. Bagent. 1967. The bollworm-tobacco budworm problem in Arkansas and Louisiana. Arkansas Agr. Exp. Sta. Bull. No. 720.

Malechek, J.C., A.M. Gray, and B.A. Haws. 1977. Yield and nutritional quality of intermediate wheatgrass infested by black grass bugs at low population densities. J. Range Manage. 30:128-130.

Rogler, G.A., and R.J. Lorenz. 1983. Crested wheatgrass-early history in the United States. J. Range Manage. 36:91-93.

Shepard, M., G.R. Carner, and S.G. Turnipaeed. 1974. A comparison of three sampling methods for arthropods in soybeans. Environ. Entomol. 3:227-232.

Smith, J.W., E.A. Stadelbacher, and C.W. Gantt. 1976. A comparison of techniques for sampling beneficial arthropod populations associated with cotton. Environ. Entomol. 5:435-444.

Tamaki, G., and R.E. Weeks. 1972. Efficiency of three predators, Geocoris bullatus, Nabis americoferus and Coccinella transversoguttata, used alone or in combination against three insect pest species, Myzus persicae, Ceramica picta, and Mamestra configurata, in a greenhouse study. Environ. Entomol. 1:258-263.

Taylor, E.J. 1949. A life history study of Nahis alternatus. J. Econ. Entomol. 42:991.

van den Bosch, R., and K.S. Hagen. 1966. Predaceous and parasitic arthropods in California cotton fields. California Agr. Exp. Sta. Bull. 820.

Whitcomb, W.H., and K. Bell. 1964. Predaceous insects, spiders, and mites of Arkansas cotton fields. Arkansas Agr. Exp. Sta. Bull. 690.

Wilson, L.T., and A.P. Gutierrez. 1980. Within-plant distribution of predators on cotton: Comments on sampling and predator efficiencies. Hilgardia 48:3-11. 